\title{
THE DISAPPEARANCE OF FOETAL HAEMOGLOBIN IN CONGENITAL CYANOTIC HEART DISEASE
}

\author{
BY \\ M. K. COGHLAN and M. C. JOSEPH \\ From the Department of Child Health and the Interdepartmental Laboratory, Guy's Hospital, London
}

(RECEIVED FOR PUbliCATION NOVEMBER 5, 1957)

Children with congenital cyanotic heart disease become adapted to some extent to anoxaemia. A well-recognized response is an increase of haemoglobin concentration; this increase might also be accompanied by a change in the type of haemoglobin formed. Foetal haemoglobin is more favourable than adult haemoglobin for oxygen uptake, and postnatal anoxaemia might promote the production of foetal haemoglobin in significant amounts. The observations reported here were made to test this hypothesis.

Adams (1952) found that in a group of 19 infants and children with congenital cyanotic heart disease foetal haemoglobin did not persist in greater amounts than in a group of normal children and adults. The range of age of the cyanosed group was wide and included infants, children, adolescents and an adult aged 30 years, but their control group did not include any infants, the youngest patient being 4 years old, and the oldest 70 years. Their mean values in the cyanosed and control groups $(6 \%$ and $3 \%$ ) exceeded the accepted upper limits of $1 \%$ to $2 \%$ in normal children and adults (Singer, Chernoff and Singer, 1951; Zannos, 1953; Huisman, Jonxis and Dozy, 1955; Jonxis and Visser, 1956).

We used the optical method of Brinkman and Jonxis (1935), with modifications (White, 1956), to estimate the proportion of foetal haemoglobin from 24 full term normal infants. We found this to be a mean value of $72 \%$ with a range of $59 \%$ to $88 \%$; this closely agrees with figures given by Schulman, Smith and Stern (1954) and Walker and Turnbull (1955). No foetal haemoglobin was demonstrated in the blood of four normal adults.

The same method was then used to determine the proportion of foetal haemoglobin present in 25 infants and children aged from 6 weeks to 8 years with Fallot's tetralogy; the cyanosis in most of these patients was severe. During the same period 22 infants and children formed a control group.

\section{Method}

Heparinized venous blood $(2.5$ to $5 \mathrm{ml}$.) was collected and the cells were washed twice with $0.85 \%$ sodium chloride and then once with $1.2 \%$ sodium chloride. The cells were then mixed with distilled water, frozen overnight and subsequently allowed to thaw at room temperature. After the addition of shredded asbestos, the stroma was removed by spinning for one hour at 3,000 r.p.m.; $0.2 \mathrm{ml}$. of the supernatant fluid was then added to $4.6 \mathrm{ml}$. of ammonium hydroxide in a cuvette and, using a Gallenkamp photometer with an Ilford 608 (red) filter, an initial reading $D_{0}$ was taken. Then $0.2 \mathrm{ml}$. of normal sodium hydroxide was added with rapid stirring and readings were taken over the next 10 minutes at 10 -second intervals, the time interval being gradually lengthened to one minute. If foetal haemoglobin was present, readings were continued for up to three hours, the final reading being $D \alpha$. The amount of haemoglobin remaining undenatured at time $(t)$ was calculated from the formula:

Amount of foetal haemoglobin present $=\frac{D_{t}-D \alpha}{D \alpha-D_{o}}$

These figures were then plotted on semilogarithmic paper using time as the abscissa and the curve obtained was extrapolated backward to cut the ordinate at a figure representing the amount of foetal haemoglobin originally present in the sample.

\section{Results}

Foetal haemoglobin was not found in any infant or child over $7 \frac{1}{2}$ months old in the cyanotic or in the control groups. Variable amounts of foetal haemoglobin were found in infants under $7 \frac{1}{2}$ months. During this period 21 estimations were made in five cyanosed and in three control infants (Table 1).

The degree of cyanosis in the five infants was severe. All were full term infants except J.H. whose 
birth weight was $3 \mathrm{lb} .1 \mathrm{oz}$. and gestation period 34 weeks. Foetal haemoglobin was not found in two infants (M.W. and P.C.) at 22 weeks, and in a further four infants (M.S., S.H., A.M. and R.S.) at 26 weeks; at this time only J.H. had foetal haemoglobin present $(9 \%)$ and this was not detectable at 30 weeks.

TABLE 1

PERCENTAGE OF FOETAL HAEMOGLOBIN IN CYANOSED AND CONTROL INFANTS

\begin{tabular}{|c|c|c|c|c|c|c|c|c|}
\hline \multirow[b]{3}{*}{$\begin{array}{r}\text { Cyanotic } \\
\text { Group }\end{array}$} & \multirow[b]{3}{*}{$\begin{array}{l}\text { J.H. } \\
\text { M.S. } \\
\text { M.W. } \\
\text { S.H. } \\
\text { D.B. }\end{array}$} & & \multicolumn{6}{|c|}{ Age in Weeks } \\
\hline & & 6 & 10 & 14 & 18 & 22 & 26 & 30 \\
\hline & & $\begin{array}{l}\% \\
\frac{61}{44} \\
=\end{array}$ & $\begin{array}{c}\% \\
40 \\
\overline{18 \cdot 5} \\
-\end{array}$ & $\begin{array}{l}\% \\
24 \\
= \\
=\end{array}$ & $\begin{array}{l}\% \\
22 \\
10 \\
\overline{7} \cdot 8\end{array}$ & $\begin{array}{r}\% \\
21 \\
0 \\
-\end{array}$ & $\begin{array}{r}\% \\
9 \\
0 \\
0 \\
\end{array}$ & $\begin{array}{l}\% \\
0 \\
= \\
=\end{array}$ \\
\hline $\begin{array}{c}\text { Control } \\
\text { Group }\end{array}$ & $\begin{array}{l}\text { P.C. } \\
\text { A.M. } \\
\text { R.S. }\end{array}$ & $\begin{array}{l}64 \\
54 \\
-\end{array}$ & $\overline{\overline{32}}$ & $\overline{-}$ & $\overline{23}$ & $\underline{0}$ & $\begin{array}{l}-\overline{0} \\
0\end{array}$ & = \\
\hline
\end{tabular}

\section{Discussion}

The oxygen curve of foetal haemoglobin lies to the left of that of adult haemoglobin, provided that the pigment is in the corpuscles (Leibson, Likhnitzky and Sax, 1936; McCarthy, 1943). This increased affinity of foetal haemoglobin for oxygen is most marked at the higher oxygen tensions. Thus, the presence of a high proportion of foetal haemoglobin is favourable for oxygen intake. Walker and Turnbull $(1953,1955)$ have stated that the rise in total haemoglobin which they have observed in the anoxic foetus at term was mainly due to an increased production of foetal haemoglobin. As term approached they found a rise in total haemoglobin which was proportional to a fall in oxygen saturation of the blood in the umbilical vein. Recently Rooth and Sjöstedt (1957) were unable to confirm this correlation.

Persistent postnatal anoxia usually causes a rise in total haemoglobin, thereby increasing the amount of oxygen available to the tissues; an increase in the proportion of foetal haemoglobin would augment this by further increasing the oxygen uptake in the lungs. Furthermore, at birth the mechanism for the formation of foetal haemoglobin is still active (Schulman et al., 1954) and under the stimulus of persistent anoxia, foetal haemoglobin would be readily formed.

The figures for J.H. (Table 1) show that, from 14 to 27 weeks, the percentage of foetal haemoglobin remained the same while during the same period the total haemoglobin rose from $9 \cdot 2 \mathrm{~g}$. $\%$ to 17.5 g. $\%$. This suggests that during this time the production of foetal haemoglobin was at least maintained.

It should be pointed out that although the method used had the disadvantage of being relatively inaccurate for amounts of foetal haemoglobin below $10 \%$ it was especially suitable for accurate measurement of larger amounts. However, foetal haemoglobin did not persist in significant amounts beyond 30 weeks in the children and infants whom we studied and the foetal pigment disappeared at about the same rate in both the cyanotic and control groups.

\section{Summary}

Blood from 25 infants and children with cyanotic congenital heart disease was tested quantitatively for foetal haemoglobin. Twenty-two normal infants and children of similar age were studied over the same period. Foetal haemoglobin was not found in any child over the age of $7 \frac{1}{2}$ months in either group.

We thank Dr. P. R. Evans and Dr. R. C. Mac Keith for their helpful criticisms. Some of the patients studied were under the care of Sir Russell Brock to whom we are grateful. We acknowledge with thanks advice given by Dr. J. C. White, Hammersmith Postgraduate School of Medicine, on the technique of estimation.

\section{REFERENCES}

Adams, F. H. (1952). J. Pediat., 40, 42.

Brinkman, R and Jonxis, J. H. P (1935) J. Physiol (Lond ), 85, 117

Huisman, T. H. J., Jonxis, J. H. P. and Dozy, A. (1955). Biochem. Biophy: Acta., 18, 576.

Jonxis, J. H. P. and Visser, H. K. (1956). A.M.A. J. Dis. Child, $92,538$.

Leluson, R. G., Likhnitzky, I. I. and Sax, M. G. (1936). J. Physiol. (Lond.), 87, 97.

McCarthy, E.F. (1943). Ibid., 102, 55.

Rooth, C. and Sjöstedt, S. (1957). Arch. Dis. Childh., 32, 91.

Schulman, J., Smith, C. H. and Stern, G. S. (1954). A.M.A.J. Dis. Chilc!., 88, 567 .

Singer, K., Chernoff, A. and Singer, L. (1951). Blood, 6, 413.

Walker, T. and Turnbull, E. P. N. (1953). Lancet, 2, 312 .

White (1955). Arch. Dis. Childh., 30, 111.

Zannos, L. (1953). Acta paediat. (Uppsala), 42, 305. 